\title{
In Defence of Ubuntu
}

\author{
Moeketsi Letseka
}

Published online: 6 October 2011

(C) The Author(s) 2011. This article is published with open access at Springerlink.com

\begin{abstract}
The article defends ubuntu against the assault by Enslin and Horsthemke (Comp Educ 40(4):545-558, 2004). It challenges claims that the Africanist/Afrocentrist project, in which the philosophy of ubuntu is central, faces numerous problems, involves substantial political, moral, epistemological and educational errors, and should therefore not be the basis for education for democratic citizenship in the South African context. The article finds coincidence between some of the values implicit in ubuntu and some of the values that are enshrined in the constitution of South Africa and that on that basis argues that ubuntu has the potential to serve as a moral theory and a public policy. The educational upshot of this article's argument is that South Africa's educational policy framework not only places a high premium on ubuntu, which it conceives as human dignity, but it also requires the schooling system to promote ubuntu-oriented attributes and dispositions among the learners. The article finds similarities between ubuntu and bildung, whose key advocates, among others was German scholar and intellectual Wilhelm von Humboldt. It argues that it would be ethnocentric, and indeed silly to suggest that the ubuntu ethic of caring and sharing is uniquely African when some of the values which it seeks to promote can also be traced in various Eurasian philosophies.
\end{abstract}

Keywords Democratic citizenship $\cdot$ Ubuntu $\cdot$ Bildung $\cdot$ Education $\cdot$ South Africa

\section{Introduction}

In this article I defend the notion of ubuntu against the assault by Enslin and Horsthemke (2004). I centre ubuntu as the conceptual heart of the article with a view to providing readers with specific ways in which African scholars have spoken of it as the philosophical basis for a unique African socio-political and economic democratic order. Ubuntu is particularly important to South Africa's young democracy. On the one hand South Africa is

\footnotetext{
M. Letseka $(\bowtie)$

Department of Educational Studies, College of Education, University of South Africa (UNISA), Pretoria 0005, South Africa

e-mail: Letsem@unisa.ac.za
} 
struggling to comprehend the enduring legacy of apartheid, which left it fractured and with no shared moral discourse. As Morrow (2007: 7) points out, "apartheid was a form of the politics of difference in that it deliberately prevented the development of social cohesion and hindered the development of a shared moral discourse". On the other hand South Africa is attempting to mobilise its peoples to embrace the constitutional values of nonracialism, non-sexism, non-discrimination, and respect for freedom, human rights and dignity. Ubuntu has a critical role to play in enabling South Africans to achieve a common understanding vis-à-vis the above-mentioned constitutional values. I highlight the key elements of ubuntu, understood as motho ke motho ka batho (in Sotho languages) and umuntu ngumuntu ngabantu (in Nguni languages). The English translation of these expressions is "a human being is a human being because of other human beings". Thus understood, ubuntu articulates social interdependence and a deep rootedness in community (Chachine 2008; Adonis 2008). The notion of social interdependence is central to theologian and philosopher Mbiti's (1971) maxim I am, because we are; and since we are, therefore I am. I highlight ubuntu's potential to serve as public policy (Nkondo 2007) and briefly commend on the coincidence between the values implicit in the constitution of South Africa and some of the key values of ubuntu (Tshoose 2009; Bekker 2006; Mokgoro 1998). I explore the view that ubuntu is a moral theory (Metz and Gaie 2010; Metz 2007; Letseka 2000; Shutte 1994), and argue that ubuntu implies an interactive ethic in which our humanity is shaped by our interaction with others as co-dependent beings (McCluskey and Lephalala 2010; Cornell and van Marle 2005).

Throughout this article I use terms such as ubuntu, African, and democracy. Let me briefly explain how I understand each of these terms. First, ubuntu. Generally ubuntu translates as humaneness, personhood and morality. Retired South African judge, Justice Mokgoro (1998) argues that ubuntu "is a humanistic orientation towards fellow beings". She contends that ubuntu envelops key values of group solidarity, compassion, respect and human dignity. For Mokgoro, the fact that the spirit of ubuntu emphasises respect for human dignity marks a shift from confrontation to reconciliation. In the same vein Letseka (2000: 180) argues that ubuntu has normative implications in that it encapsulates moral norms and values such as "altruism, kindness, generosity, compassion, benevolence, courtesy, and respect and concern for others”. For Letseka (2000: 188), persons living in communities that embrace ubuntu would be marked by a commitment to treating others with a sense of botho or ubuntu, which entails treating them with justice and fairness. Broodryk (2002: 13) conceives ubuntu as a comprehensive ancient African worldview based on the values of humanness, caring, sharing, respect, compassion and associated values. Against the backdrop of these understandings I submit that the promotion of ubuntu through education is critical for South Africa given that the country has only just emerged from a political era that was marked by civil strife, racial segregation and discrimination, subordination and domination, and exclusion.

I use the term Africa in its geographic sense to mark out Africa as different from Europe, Asia, Oceania, North and South America. Thus the adjective African has geographic, cultural and political slants. That said, I should hasten to mention that I do not presume any homogeneity about Africa or anything African. As Appiah (1997: 47) reminds us, the central cultural fact of Africa's life remains not the sameness of Africa's cultures, but their enormous diversity. Appiah argues that long before Charlemagne was crowned, the ancestors of the San people of southern Africa were living free of rulers, in nomadic family groups. But African kingship in Egypt was millennia old. When the American republic began, there were matrilineal kingdoms in Asante and patrilineal kingdoms in Yorubaland. There were female regiments in Dahomey, and high-born Hausa 
women living in enclosed Moslem households in Kano in what is now upper Nigeria; cats were food for the Mossi in West Africa and taboo for the Asante; and the range of clothing across the continent included most of the forms of dress (and undress) that the human species has known. Indeed as I will show later, there are other non-African world views that can be said to share similar traits with ubuntu. As case in point I will make brief remarks on the notion of bildung.

Democracy is one of the concepts that have been described as "essentially contested" (Gallie 1956). This is not unusual given that democracy has been viewed by others as muddled (Macpherson 1966), as paradoxical (Dahl 2000), as fuzzy (Davis 2005), as vexed (Laurence 1997), and as confusing and unsettled (Held 1987). In that respect democracy does not consist of a single unique set of institutions. Rather, there are many types of democracy, and their diverse practices produce a similarly varied set of effects (Schmitter and Karl 1991: 76). For instance, while electoral, majoritarian or procedural forms of democracy might be preferable to autocracy and military dictatorship, they do not always produce similar effects. In this article I use the concept of democracy to refer to a social order that is marked by the existence of freedoms and rights for individuals to exercise choice. As Ake (1987: 6) puts it, "there is no democracy where there is no liberty for selfexpression or choice. At the same time there is no democracy where there is no equality for inequality reduces human relations to subordination and domination". I am mindful that while elections may be preferable as a form of publicly exercising one's choice, it does not necessarily follow that regularly holding elections equals democratisation (Diamond 2002; Leiva and Veltmeyer 1994). In what Diamond (2002: 23) describes as 'hybrid regimes' or 'political gray zone', some countries can be electoral democracies and yet fall between full-fledged democracies and outright dictatorships. Citing Huntington (1991), Diamonds argues that a system is democratic when "its most powerful collective decision makers are selected through fair, honest, and periodic elections in which candidates freely compete for votes".

This article is divided into four sections. In "Enslin and Horsthemke's Assault on Ubuntu" section I sketch Enslin and Horsthemke's assault on ubuntu and Africanism/ Afrocentrism and offer responses where necessary. In "Ubuntu as a Moral Theory and Public Policy" section I commend on the potential for ubuntu for to serve as a public policy and as moral theory. In "Ubuntu as an Educational Value in South Africa" section I briefly sketch the role of ubuntu in South Africa's educational policy framework. I argue that this is consistent with the view alluded to above that some of the values implicit ubuntu coincide with some of values implicit in the country's constitution. In "Conclusion" section I provide some concluding remarks.

\section{Enslin and Horsthemke's Assault on Ubuntu}

In a useful article titled "Can ubuntu provide a model for citizenship education in African democracies?", Enslin and Horsthemke (2004) critique the view that education for democratic citizenship should be based on local or regional foundations. Their critique is directed at "an essay published in the Sunday Times several years ago" by Malegapuru William Makgoba (1996). Enslin and Horsthemke (2004: 548-549) take issue with Makgoba's characterization of classical Western democracies and liberal philosophy, the account given of ubuntu and its purported usefulness as a principled action guide. They dismiss these as dubious, regressive, and pernicious. The position of their paper involves several related claims which they list as follows: 
- Democracy is essentially 'embedded', i.e. it is a local, indigenous phenomenon. Its manifestations differ according to social and cultural context.

- African democracy is distinct and unique.

- Africanism/Afrocentrism is a valid perspective from which to view democracy and citizenship education.

- In the context of (South) Africa, only ubuntu, the African principle of human interdependence, provides a suitable democratic model. African culture and identity are ill served by other democratic models.

- The community has priority over the individual. Communalism is ethically superior to individualism, which is frequently equated with egoism and selfishness.

- African traditional education provides an adequate and fertile ground for democratic citizenship.

It seems odd though that Enslin and Horsthemke opted to critique a newspaper article while there is an abundance of South African scholars who have published their views on these issues in scholarly journals and books (Bekker 2006; Ramose 2002, 1999; Broodryk 2002; Sindane and Liebenberg 2000; Tutu 1999; Mokgoro 1998; Sindane 1994). I now briefly respond to some of Enslin and Horsthemke's assumptions on African democracy, ubuntu and community.

\section{Democracy as Essentially Embedded}

Let me start with the issue of whether democracy is essentially embedded, is a local, indigenous phenomenon, and its manifestations differ according to the social and cultural context. Democracy is one of the concepts that William B. Gallie (1956) described as 'essentially contested concepts' in a paper he read during the meeting of the Aristotelian Society in London on 12th March 1956. The other concepts are art, social justice and Christian life. Gallie (1956: 169) argues that such concepts are essentially contested because they inevitably involve endless disputes about their proper use on the part of their users. Other theorists have drawn on Gallie's formulation to debate, among others, whether democracy (Collier et al. 2006; Baker and Hughes 2000), philosophy and politics (Newey 2001), liberalism (Abbey 2005; Gray 1978), the rule of law (Waldron 2002), education (Enslin 1993), citizenship (Carr 1991), freedom (Day 1986), power (Lukes 1974), rape (Reitan 2001), abortion (Gibson 2004), and medicine (McKnight 2003) are 'essentially contested concepts'. MacIntyre (1973) draws on Friedrich Waismann's notion of 'the open texture of concepts' to debate the essential contestation of some social concepts. If we accept Gallie's formulation above as valid, it follows that whether democracy is essentially embedded or not is itself an integral feature of the contested nature of democracy. As Bratton and Mattes (2001: 108) point out, "democracy means different things to different people". Dieltiens and Enslin (2002: 7) argue that "various formulations of democracy exist with some theorists claiming to be true democrats according to the relative weight they give to particular indices". While Collier and Levitsky (1997) contend that democracy is a complex concept. Collier and Levitsky identify 550 examples of democracy 'with adjectives', and are concerned that the various definitions do not help resolve what democracy really is.

It seems that while the embeddedness of democracy is one of the targets of their critique, in principle Enslin and Horsthemke (2004: 550) do not dispute it. For instance, they acknowledge that communitarians and defenders of ubuntu as an appropriate underpinning for both democracy and education have a point in their concern that 
institutions like schools, and the values they reflect, should cohere with the cultures of those they serve. They argue that the need for cultural coherence requires that citizens should feel at home in the institutions that serve their needs, and that this requires that the everyday practices of schools and politics should be welcoming and familiar rather than exclusionary and alienating (Enslin and Horsthemke 2004: 551). They endorse Meira Levinson's (1999) view that individuals must be able to feel embedded within a culture or a set of cultures, and to mediate their choices via the norms constitutive of such cultures. The view that individuals are embedded is recognised by liberal theorists such as Dworkin (1988: 15), who argues that individuals develop socially and psychologically in a given environment with a set of biological endowments. They mature slowly and are, therefore heavily influenced by parents, peers, and culture. While for Etzioni (1999: 94), "the ability to make rational choices, to be free, presumes that the person is embedded in a social fabric". It seems reasonable for me to argue that there is nothing wrong with democracy being a local, indigenous phenomenon. That is, being embedded.

\section{African Democracy as Distinct and Unique}

Enslin and Horsthemke pick on Makgoba's (1996) claim that "ubuntu seems logical in our [South African] situation because our democracy is unique in that it must evolve from the beginning within a multiracial and multicultural context. It must deliver freedom with opportunities while addressing values and cultural systems". They argue that the idea that "the transcending philosophy of African ubuntu could provide a distinctive underpinning for democracy in South Africa presents an immediate anomaly" (Enslin and Horsthemke 2004: 552). They contrast the values implicit in ubuntu with the values implicit in the South African Constitution-its strong emphasis on freedom and equality; its bearing all the hallmarks of a liberal democracy; its Lockean requirement that the powers of the legislature, executive and judiciary be separated; its protection of a range of rights, including privacy, freedom of religion, belief and opinion, expression, assembly and association, as well as freedom and security of the person, children's rights and the right to basic education; its conferment of a universal adult franchise on citizens who are protected by it against infringements of their rights by the state, and its provision for public consultation by the national and provincial legislatures to gather a range of opinions on proposed legislation.

Let me briefly sketch developments in the South African legal landscape that have positioned ubuntu as a constitutional value (Bekker 2006; Barrie 2000; Mokgoro 1998; English 1996). Retired Justice Mokgoro (1998: 1) notes that "the concept of ubuntu, like many concepts, is not easily defined. Defining an African notion in a foreign language and from an abstract, as opposed to a concrete approach, defies the very essence of the African worldview and may also be particularly illusive". Mokgoro's views are shared by Anglican Archbishop Desmond Tutu (1999: 34), who argues that "ubuntu is very difficult to render into Western language". Notwithstanding these concerns Mokgoro (1998) posits that ubuntu, a Zulu word for botho as its Sesotho equivalent, has been described as a worldview of African societies and a determining factor in the formation of perceptions which influence social conduct. This is echoed by Broodryk (2002: 13), who argues that ubuntu is a comprehensive ancient African worldview based on the values of intense humanness, caring, sharing, respect, compassion and associated values. In the same vein Ramose (2002: 230) argues that ubuntu is the wellspring flowing with African ontology and epistemology. A persuasive philosophical argument can be made that there is a 'family atmosphere', that is, a kind of philosophical affinity and kinship among and between the 
indigenous people of Africa, which is captured in the maxim motho ke motho ka batho (Sotho), or its Nguni variation: umuntu ngumuntu nga bantu, whose English translation approximates something like: "a person is a person through other persons". Against the backdrop of these views I do not find any anomaly in the suggestion that the normative values implicit in ubuntu have the potential to provide a distinctive underpinning for democracy in South Africa.

Enslin and Horsthemke (2004: 549) argue that there is no distinctly or uniquely African democracy. I beg to differ with them. Let me qualify my position. For me there should be no doubt, at least at an empirical level, about the uniqueness of African democracy. Claude Ake makes a compelling case for the uniqueness of African democracy. He argues that democracy has to be recreated in the context of the given realities in political arrangements which fit the cultural context, without sacrificing its values and inherent principles. In Africa this fit entails, among other things, a con-societal arrangement-the use of ethnic groups, nationalities and communities as the constituencies for representation (Ake 1993: 244). Ake (1993: 241) argues in order for African democracy to be relevant and sustainable, it has to de-emphasize abstract political rights and stress concrete economic rights because the demand for democracy in Africa draws much of its impetus from the prevailing economic conditions. He posits that ordinary Africans do not separate political democracy from economic democracy, or for that matter from economic well-being. They see their political empowerment, through democratisation, as an essential part of getting the economic agenda right at last and ensuring that their development project is managed better and its rewards more evenly distributed. In this regard a unique African democracy is not something that will emerge from a rational blueprint: it will emerge from practical experience and improvisation in the course of a hard struggle. The process towards democracy must be shaped by the singular reality that those whose democratic participation is at issue are ordinary peoples, many of whom are illiterate, poor, rural dwellers in essentially pre-industrial and communal society (1993: 243). For Ake, "Africa is still a communal society, and it is this communalism which defines the people's perceptions of self-interest, their freedom and their location in the social whole". South Africa's democracy has begun to show worrying fault-lines when viewed against the backdrop of the material conditions of existence of millions of the Africa peoples, many of whom are illiterate, poor, rural and informal settlement dwellers. It is a democracy marked by extreme societal inequalities between the rich and the poor.

Mbeki (1998) made a case for South Africa as 'Two Nations', drawing on Sir Benjamin Disraeli's (1980) novel Sybil, or Two Nations. He described one of these nations as white, relatively prosperous, with ready access to a developed economy, physical, educational, communication and other infrastructure. And he described the other nation as black and poor, with the worst affected being women in rural areas, the black rural population in general and the disabled, who live under conditions of a grossly underdeveloped economic, physical, educational, communication and other infrastructure. For making such a critical and necessary observation Mbeki was vilified. Nattrass and Seekings (2001a, b) took issue with him for reducing inequality to race, that is, black equals poor and white equals rich. Nattrass and Seekings argued that by emphasizing interracial economic inequality Mbeki misunderstood the changing nature of inequality in South Africa. They posited that inequality in post-apartheid South Africa was driven by two income gaps between an increasingly multiracial upper class and everyone else, and between a middle class of mostly urban, industrial, or white-collar workers and a marginalized class of black and rural poor. 
It is my view that Nattrass and Seekings glossed over South Africa's racially skewed labour market in which whites continue to hold most skilled occupations and senior management positions while Africans continue to swell the ranks of juniors and support staff (Econometrix Ecobulletin 2007; Moleke 2006, 2005; Pauw et al. 2006; Bhorat and Oosthuizen 2005; Bhorat 2004). Moleke (2005: 2) argues that because of discrimination and acquired human capital "South Africa's labour market is characterized by racial job segregation both between sectors and between occupational categories". She contends that "whites are still overrepresented in skilled occupations and their representation at seniormanagement level is also relatively high" (Moleke 2006: 4). According to the Econometrix Ecobulletin (2007), while the proportion of Africans in top management increased from $6.2 \%$ in 2000 to $11.3 \%$ in 2006, the proportion of whites was 87.5 and $74.4 \%$ respectively. The proportion of Africans in senior management positions increased from $8.7 \%$ in 2000 to $13.4 \%$ in 2006 , while the proportion of whites was 81.6 and $70.9 \%$ respectively. Similarly the proportion of professionally qualified Africans declined from $32.8 \%$ in 2000 to $20.2 \%$ in 2006 while the proportion of professionally qualified whites increased from 56.1 to $61.2 \%$. Unemployment rates for whites during 2001-2007 ranged between 5 and 4.8\%, which was way below the national average of $31.5 \%$, while unemployment rates for Africans were between 30 and $37 \%$, at one stage well above the national average (Letseka 2009). To reiterate Ake's (1987) views above, there is no democracy where there is no equality because inequality reduces human relations to subordination and domination. It is my view that ubuntu as humanness, caring, sharing, respect, compassion (Broodryk 2002) and as kindness, generosity, compassion, benevolence, courtesy, and concern for others (Letseka 2000), could be a useful tool for understanding these deep socio-economic inequalities.

\section{Whether Community is Prior to the Individual}

The issue of whether the community has priority over the individual or whether communalism is ethically superior to individualism dominated social science debates in the 1980s when the liberal-communitarian debate burst into the open. I acknowledge that there are subtle crosspollinations between some traditional African socio-political and cultural practices and some Western socio-political and cultural practices, or what Wolf (1982: 4) calls "linkages and interrelationships". In this regard the work of Canadian philosopher Charles Taylor is very instructive. Taylor (1996: 3) argues that it is possible for someone to have a communitarian or holist ontology and to value liberalism's individual rights. He contends that often the choice is not simply between a close, family-like community and a modern, impersonal society (Taylor (1991: 161). In the same vein, British liberal philosopher Isaiah Berlin (1969: 143) argues that "men are largely interdependent that no man is so completely private as never to obstruct the lives of others in any way". As Wiredu (1996: 72) points out, the distinction between communalism and individualism is one of degree only. A considerable value may be attached to communality in individualistic societies, just as individuality is not necessarily trivialized within communalism. The two orientations can co-exist in different sectors of the same society.

In the two sections below I expound on the specific ways in which ubuntu can serve as the philosophical basis for a unique African socio-political and economic democratic order. I briefly tease out the coincidence between some of the values implicit in the constitution of South Africa and some of the values implicit in ubuntu and commend of ubuntu's educational upshot. It is my contention that ubuntu has the potential to serve as both a moral theory and public policy. That is, it has normative implications that can guide public policy. 


\section{Ubuntu as a Moral Theory and Public Policy}

The questions, what does it mean to be African? How does one speak of an African, and for what purpose, are critical to understandings of the notion of ubuntu and its perceived importance to African communities. Mudimbe (1985: 194) raises similar and very critical questions when he asks, in which areas and against which background is the knowledge of the African's being to be deposited? How does one define this very being, and from which authority could one provide a foundation for possible answers. For Mudimbe (1985: 150), the ways in which the African Weltanschauungen and African traditional systems have been thought of and the means used to explain them relate to theories and methods whose constraints, rules, and systems of operation suppose a non-African epistemological locus. For me, central to the debate on ubuntu is the need to clarify, and hopefully have common understandings on what it means to be 'an African'. For instance, when Mbeki (1998: 32) described himself as 'an African', as the grandchild of the warrior men and women that Hintsa and Sekhukhune led, the patriots that Cetshwayo and Mphephu took to battle, the soldiers Moshoeshoe and Ngungunyane taught never to dishonour the cause of freedom, he was not simply appealing to nationalistic populism. On the contrary, he was articulating his perception of his African identity. I grew up in a rural African homestead in Lesotho which identified itself as the Bafokeng, a totem group associated with the rabbit. I was taught to proudly assert my Bofokeng-my identity as a Mofokeng. It is a norm among the Basotho to dare one to praise one's totem group. Such praises take the form of oral historical recitations of one's family which are passed from generation to generation and whose knowledge is highly valued and treated as a signifier of one's identity. It is my view that at the heart of the debates on ubuntu is how people, in this case the African peoples, perceive ubuntu as a worldview that embodies their notions of morality and personhood.

\section{Ubuntu as a Moral Theory}

A common thread running through the work of Metz and Gaie (2010), Metz (2007), Bessler (2008), Broodryk (2002), Ramose (1999, 2002), Letseka (2000), Sindane and Liebenberg (2000), Sindane (1994), Tutu (1999), Mokgoro (1998), Shutte (1994), Teffo (1994), to mention a few, is the conviction that ubuntu is a moral theory. That is, it serves as a cohesive moral value in the face of adversity (Teffo 1994). Bessler (2008: 43) argues that in South Africa the culture of ubuntu is the capacity to express compassion, justice, reciprocity, dignity, harmony and humanity in the interests of building, maintaining and strengthening the community. Ubuntu articulates our inter-connectedness, our common humanity and the responsibility to each that flows from our connection. It is a worldview that emphasises the commonality and interdependence of the members of the community. Umuntu ngumuntu ngabantu or "a human being is a human being because of other human beings" resonates with Mbiti's (1971) maxim I am, because we are; and since we are, therefore I am, which articulates social interdependence or a deep rootedness in community (Chachine 2008; Adonis 2008). For Sindane (1994: 8-9), "ubuntu inspires us to expose ourselves to others, to encounter the difference of their humanness so as to enrich our own".

Metz (2007: 240) argues that ubuntu is a theory of right action. He writes that "the most justified normative theory of right action that has an African pedigree is the requirement to produce harmony and to reduce discord, where harmony is a matter of identity and solidarity". It is Metz's contention that ubuntu is fundamentally a matter of reverence of human life. Valuing human life or thinking of others as worthy of flourishing is part of 
loving others or promoting harmony. In my introductory remarks above I alluded to a coincidence between some key values of ubuntu and values implicit in the constitution of South Africa (Tshoose 2009; Bekker 2006; Mokgoro 1998). One such area of coincidence is human dignity. Metz (2007: 329) cites a judgement by Justice Mokgoro in the Constitutional Court of South Africa in which she states that "life and dignity are like the two side of the same coin. The concept of ubuntu embodies them both". The notion of human dignity is at the heart of the constitution of South Africa, especially Chapter 2-Bill of Rights. Let me briefly elaborate. Section 9 (1) states that "everyone is equal before the law and has the right to equal protection and benefit of the law". Section 9 (2) conceives of equality as "the full enjoyment of all rights and freedoms". Section 9 (3) protects these rights and freedoms. It states that "the state may not unfairly discriminate directly or indirectly against anyone on one or more grounds, including race, gender, sex, pregnancy, marital status, ethnic or social origin, colour, sexual orientation, age, disability, religion, conscience, belief, culture, language and birth". Sections 10 and 11 affirm the right to respect and protection of everyone's dignity, and the right to life. Like South Africa's constitution ubuntu accords "all human beings a moral status and considers everyone in principle to be potential members of an ideal family based on loving or friendly relationships" (Metz and Gaie 2010: 281). It is my firm belief that ubuntu has the potential to foster a shared moral discourse which is a characteristic of a cohesive society (Morrow 2007: 6). As Swanson (2005: 4) puts it, the struggle for ubuntu serves as a philosophy of the struggle for people trying to heal the brutality and desperateness of a deeply ruptured society. In heart-felt terms, the struggle for ubuntu is the struggle for the dignity and soul of South Africa.

I want to argue that a case of similarities between ubuntu and bildung can be made. Louw (2001: 28) rightly cautions that "it would be ethnocentric and, indeed, silly to suggest that the ubuntu ethic of caring and sharing is uniquely African. After all, the values which ubuntu seeks to promote can also be traced in various Eurasian philosophies". German scholar and intellectual Wilhelm von Humboldt expounded on the notion of bildung in his Theory of Bildung. He argued that bildung is about linking the self to the world in the most general, most animated and most unrestrained interplay. Humboldt understood bildung as mimetic, that is, as non-teleological, undetermined and uncertain, and aimed at the reconciliation between outer historico-social and inner individual conditions (Wulf 2003). For Humboldt, bildung requires interchange between individuals. It is a political and social harmony which must be achieved in the modem state (Sorkin 1983: 60). Sorkin (1983: 68) notes that for Humboldt, there is an internal moral imperative which makes bildung become the basis of politics. Løvlie and Standish (2002: 319) contend that in the world of bildung the self is never a lonely wanderer, but always already involved, such that the opposition between the self and the world is not a contingent one but expresses a necessary relation. In other words, bildung starts with the individual embedded in a world that is at the same time that of the differentiated other. For Biesta (2002: 380), the modern conception of bildung articulates an educational ideal that, through the Enlightenment, has gained a political significance in that it has become intimately connected with an emerging civil society and with a specific conception of the ideal citizen in such a society.

\section{Ubuntu as Public Policy}

Nkondo (2007: 88) makes a case for integrating ubuntu in South Africa's national policy. He argues that ubuntu can be connected with the imperatives of political power and democracy. As public policy ubuntu has the potential to contribute significantly to the 
development of an ethical disposition that can enable us to reach out beyond narrow racial and ethnic identities (Nkondo 2007: 94). Given some of the values that are implicit in ubuntu, such as altruism, kindness, generosity, benevolence, courtesy, and respect for others, Nkondo contends that ubuntu has the potential to deepen our disposition for compassion and caring. He opines that the political ideal of ubuntu associated with communalism seeks to reconcile two ideals: first, the idea that society possesses a morally privileged status that should be enshrined and protected by certain inviolable rights and freedom against exploitation and domination (Nkondo 2007: 95). And second, that the rights and freedoms of the individual should not be in conflict with the common good. The ubuntu-based political ideal is founded on the idea that we live in a moral space mapped by strong values, that one's social world provides a framework which defines the shape of a life worth living (Nkondo 2007: 95). Thus under ubuntu conditions political thinking would involve interpretation of shared understandings and meanings bearing on the political life of one's community. Persons would realise themselves in the process of acting with others, in social practice (Nkondo 2007: 96).

\section{Ubuntu as an Educational Value in South Africa}

Nkondo (2007: 98) argues that the education system needs to play a more effective role in the political, social and economic reordering of the state and society. He contends that what is needed is for education to articulate a methodology for developing an ubuntu social disposition. He is of the view that an ubuntu-oriented framework could be the engine and elixir for transformation, particularly if a clear methodology existed for the integration of its principles into a national system of education and training. Against the backdrop of Nkondo's concern about the role of ubuntu in education it should be noted that South Africa's Department of Education's (DoE) (2001: 12) report, Manifesto on Values, Education and Democracy identifies ten fundamental values in the South African constitution that pertain to education. These are democracy, social justice and equity, equality, nonracism and non-sexism, ubuntu (human dignity), an open society, accountability, the rule of law, respect, and reconciliation. The report states that ubuntu embodies the concept of mutual understanding and the active appreciation of the value of human difference (DoE 2001: 3). It posits that out of the values of ubuntu and human dignity flow the practices of compassion, kindness, altruism and respect, which are at the very core of making schools places where the culture of teaching and the culture of learning thrive (DoE 2001: 14).

Another report of the DoE (2000: 10), Values, Education and Democracy proposes that education should equip young people with values such as honesty, integrity, tolerance, diligence, responsibility, compassion, altruism, justice and respect, which are deemed necessary for a democratic livelihood. The report states very clearly that the schooling system should actively promote these values. It posits that an educational philosophy of a democracy should develop intellectual abilities and critical faculties among children and young adults in schools. It deems this necessary, first, because a democratic society flourishes when citizens are informed by a grasp of their history and of current affairs, where nothing is beyond question, and where ideas are explored to their fullest extent (DoE 2000: 6). Second, the report states that such an educational philosophy should include all learners irrespective of their backgrounds. This is necessary for the promotion of cultural tolerance and appreciation of difference. Third, such an educational philosophy should equip learners with the tools to resolve the many problems that come with being human. One of these tools is the attitude to treat problems as challenges that need to be resolved 
through knowledge and understanding rather than to be regarded as unbearable burdens that are to be endured without solution (DoE 2000: 10-11). I need to mention that the development of critical faculties among learners is one of the aims of South Africa's educational policy framework. For instance, section 17 of the White Paper on Education and Training (1995) requires the curriculum, teaching methods and textbooks at all levels and in all programs of education and training to encourage independent and critical thought, the capacity to question, enquire, reason, weigh evidence and form judgments, achieve understanding, recognize the provisional and incomplete nature of most human knowledge, and communicate clearly. Whether the current crop of teachers in the country's schooling system has the capacity to sufficiently deliver this very important policy aim is a matter for another debate. That said, it is my contention that development of critical dispositions among learners at school level is pertinent to the promotion of ubuntu-oriented attributes and dispositions.

\section{Conclusion}

What I have attempted to do in this article is to defend ubuntu and Africanism/Afrocentrism against the assault by Enslin and Horsthemke (2004). I have argued that understood as "a human being is a human being because of other human beings" ubuntu articulates social interdependence or a deep rootedness in community. I have highlighted the coincidence between the values implicit in South Africa's constitution and some of the key values of ubuntu and argued that ubuntu has the potential to serve as a moral theory and a public policy. On the one hand South Africa's constitution enshrines a wide range of rights and freedoms for citizens and affirms the democratic values of equality and human dignity. On the other hand ubuntu reveres human life, dignity, respect, caring and compassion. To reiterate Metz (2007), ubuntu is fundamentally a matter of reverence of human life. I showed that ubuntu, understood as human dignity is at the heart of South Africa's educational policy framework, which requires the schooling system promote it. The kind of learner envisaged by South Africa's educational policy framework is one who will act in the interests of a society based on respect for democracy, equality, human dignity, life and social justice. In this regard the schooling system is required to create a lifelong learner who is confident and independent, literate, numerate, multi-skilled, compassionate, with the ability to participate in society as a critical and active citizen (DoE 2002). This is regarded as part of the drive towards developing a common understanding and tolerant dispositions in a country that was deeply fractured by apartheid policies and had no shared moral discourse. Ubuntu role in these policy initiatives cannot be overemphasised.

Open Access This article is distributed under the terms of the Creative Commons Attribution Noncommercial License which permits any noncommercial use, distribution, and reproduction in any medium, provided the original author(s) and source are credited.

\section{References}

Abbey, R. (2005). Is liberalism now an essentially contested concept? New Political Science, 27(4), 461-480.

Adonis, C. K. (2008). Trans-generational trauma and humiliation, its potential implications for political forgiveness in post-apartheid South Africa, paper presented at the International Peace Research Association Global conference, University of Leuven, Belgium, 15-19 July. 
Ake, C. (1987). The African context of human rights. Africa Today, 34(1-2), 5-12.

Ake, C. (1993). The unique case of African democracy. International Affairs, 69(2), 239-244.

Appiah, K. A. (1997). The arts of Africa. The New York Review of Books, 44(7), 46-51.

Baker, B., \& Hughes, A. (2000). Introduction. Commonwealth \& Comparative Politics, 38(3), 1-8.

Barrie, G. N. (2000). Umuntu ungamntu ngabanye abantu: The recognition of minority rights in the South African Constitution. Journal of South African Law, 11(2), 271-278.

Bekker, T. (2006). The re-emergence of ubuntu: A critical analysis. South African Public Law, 21(2), 333-344.

Berlin, E. (1969). Four essays on liberty. Oxford: Oxford University Press.

Bessler, J. D. (2008). In the spirit of ubuntu: Enforcing the rights of orphans and vulnerable children affected by HIV/AIDS in South Africa. Hastings International and Comparative Law Review, 31(1), 33-113.

Bhorat, H. (2004). Labour market challenges in the post-apartheid South Africa. South African Journal of Economics, 72(5), 940-977.

Bhorat, H., \& Oosthuizen, M. (2005). The post-apartheid South African labour market, working paper, Development Policy Research Unit (DPRU), University of Cape Town.

Biesta, G. (2002). How general can Bildung be? Reflections on the future of a modern educational ideal. Journal of Philosophy of Education, 36(3), 378-390.

Bratton, M., \& Mattes, R. (2001). How people view democracy: Africans' surprising universalism. Journal of Democracy, 12(1), 107-121.

Broodryk, J. (2002). Ubuntu: Life lessons from Africa. Pretoria: Ubuntu School of Philosophy.

Carr, W. (1991). Education for citizenship. British Journal of Educational Studies, 39(4), 373-385.

Chachine, I. E. (2008). Community, justice, and freedom: Liberalism, communitarianism, and African contributions to political ethics. Unpublished $\mathrm{PhD}$ dissertation, Department of Theology, Studies in Faith and Ideologies, Uppsala University, Sweden.

Collier, D., Hidalgo, D., \& Andra, F. O. (2006). Essentially contested concepts: Debates and applications. Journal of Political Ideologies, 11(3), 211-246.

Collier, D., \& Levitsky, S. (1997). Democracy with adjectives: Conceptual innovation in comparative research. World Politics, 49(3), 430-451.

Cornell, D., \& van Marle, K. (2005). Exploring ubuntu: Tentative reflections. African Human Rights Law Journal, 5(2), 195-220.

Dahl, R. A. (2000). A democratic paradox. Political Science Quarterly, 115(1), 35-40.

Davis, J. W. (2005). The fuzzy concept of democracy, paper presented at the Annual meeting of the American Political Science Association, 1-4 September, Washington, DC.

Day, P. (1986). Is the concept of freedom essentially contestable? Philosophy, 61(235), 116-123.

Department of Education. (1995). White paper on education and training. Pretoria: Department of Education.

Department of Education. (2000). Values, education and democracy. Pretoria: Department of Education.

Department of Education. (2001). Manifesto on values, education and democracy. Pretoria: Department of Education.

Department of Education. (2002). Revised National Curriculum Statement for Grades R-9 (Schools). Pretoria: Department of Education.

Diamond, L. (2002). Thinking about hybrid regimes: Elections without democracy. Journal of Democracy, $13(2), 21-35$.

Dieltiens, V., \& Enslin, P. (2002). Democracy in education or education for democracy: The limits of participation in South African school governance. Journal of Education, 28, 5-25.

Disraeli, B. (1980). In T. Braun (Ed.), Sybil or the two nations. Harmondsworth, Middlesex: Penguin Books.

Dworkin, G. (1988). The theory and practice of autonomy. Cambridge: Cambridge University Press.

Econometrix Ecobulletin. (2007). Employment equity and skills shortage: Myths and realities, no. 15107, 23 July.

English, R. (1996). Ubuntu: The quest for indigenous jurisprudence. South African Journal on Human Rights, 12(4), 641-648.

Enslin, P. (1993). Should nation-building be an aim of education? Inaugural lecture delivered at the University of the Witwatersrand, Johannesburg, 22 September.

Enslin, P., \& Horsthemke, K. (2004). Can ubuntu provide a model for citizenship education in African democracies? Comparative Education, 40(4), 545-558.

Etzioni, A. (1999). Debate: The good society. Journal of Political Philosophy., 7(1), 88-103.

Gallie, W. B. (1956). Essentially contested concepts. Proceedings of the Aristotelian Society, 56(2), $167-198$.

Gibson, S. (2004). The problem of abortion: Essentially contested concepts and moral autonomy. Bioethics, $18(3), 221-233$. 
Gray, J. (1978). On Liberty, liberalism and essential contestability. British Journal of Political Science, 8(4), $385-402$.

Held, D. (1987). Models of democracy. Oxford: Polity Press.

Huntington, S. P. (1991). The third wave: Democratization in the late twentieth century. Norman: University of Oklahoma Press.

Laurence, W. (1997). The vexed issue of the meaning of democracy. Journal of Political Ideologies, 2(2), $121-130$.

Leiva, F. I., \& Veltmeyer, H. (1994). Democracy and poverty in Chile: The limits to electoral democracy. Boulder, Colorado: Westview Press.

Letseka, M. (2000). African philosophy and educational discourse. In P. Higgs, N. C. G. Vakalisa, T. V. Mda, \& N. T. Assie-Lumumba (Eds.), African voices in education. Cape Town: Juta.

Letseka, M. (2009). University drop-out and researching work and learning. In S. Walters \& L. Cooper (Eds.), Learning/work: Turning work and lifelong learning inside. Cape Town: HSRC Press.

Levinson, M. (1999). The demands of liberal education. Oxford: Oxford University Press.

Louw, D. J. (2001). Ubuntu and the challenges of multiculturalism in post-apartheid South Africa. Quest, 15(1-2), 15-26.

Løvlie, L., \& Standish, P. (2002). Introduction: Bildung and the idea of a liberal education. Journal of Philosophy of Education, 36(3), 317-340.

Lukes, S. (1974). Power: A radical view. London: Macmillan.

MacIntyre, A. (1973). The essential contestability of some social concepts. Ethics, 84(1), 1-9.

Macpherson, C. B. (1966). The real world of democracy. Oxford: Clarendon Press.

Mbeki, T. M. (1998). Africa the time has come: Selected speeches of Thabo Mbeki. Johannesburg: Mafube Publishers.

Mbiti, J. S. (1971). African traditional religions and philosophy. New York: Doubleday.

McCluskey, G., \& Lephalala, M. (2010). 'A person is a person because of others': Meanings of discipline in South African and UK schools. Power and Education, 2(1), 18-30.

McKnight, C. (2003). Medicine as an essentially contested concept. Journal Medical Ethics, 29(4), 261-262.

Metz, T. (2007). Towards an African moral theory. The Journal of Political Philosophy, 15(3), 321-341.

Metz, T., \& Gaie, J. B. R. (2010). The African ethic of Ubuntu/Botho: Implications for research on morality. Journal of Moral Education, 39(3), 273-290.

Mokgoro, Y. (1998). Ubuntu and the law in South Africa. Buffalo Human Rights Law Review, 15, 1-6.

Moleke, P. (2005) Inequalities in higher education and the structure of the labour market. Occasional paper, Cape Town: HSRC Press.

Moleke, P. (2006). After ten years of employment equity, it's still business as usual. HSRC Review, 4(10), 4-5.

Morrow, W. (2007). Learning to teach in South Africa. Cape Town: HSRC Press.

Mudimbe, V. Y. (1985). African Gnosis philosophy and the order of knowledge: An introduction. African Studies Review, 28(2/3), 149-233.

Nattrass, N., \& Seekings, J. (2001a). Democracy and distribution in highly unequal economies: The case of South Africa. Journal of Modern African Studies, 39(3), 471-498.

Nattrass, N., \& Seekings, J. (2001b). Two nations? Race and economic inequality in South Africa today. Daedalus: Journal of the American Academy of Arts and Sciences, 130(1), 45-70.

Newey, G. (2001). Philosophy, politics and contestability. Journal of Political Ideologies, 6(3), $245-261$.

Nkondo, G. M. (2007). Ubuntu as public policy in South Africa: A conceptual framework. International Journal of African Renaissance Studies, 2(1), 88-100.

Pauw, K., Bhorat, H., Goga, S., Ncube, L., \& Van de Westhuizen, C. (2006). Graduate unemployment in the context of skills shortages, education and training: Findings from a firm survey, working paper 06/115, Development Policy Research Unit (DPRU), University of Cape Town.

Ramose, M. B. (1999). African Philosophy through Ubuntu. Harare: Mond Books Publishers.

Ramose, M. B. (2002). The philosophy of ubuntu and ubuntu as a philosophy. In P. H. Coetzee \& A. P. J. Roux (Eds.), Philosophy from Africa: A text with readings. Cape Town: Oxford University Press.

Reitan, E. (2001). Rape as an essentially contested concept. Hypatia, 16(2), 43-66.

Schmitter, P. C., \& Karl, T. L. (1991). What democracy is ... and is not. Journal of Democracy, 2(3), 75-88.

Shutte, A. (1994). Philosophy for Africa. Rondebosch: UCT Press.

Sindane, J. (1994). Ubuntu and nation building. Pretoria: Ubuntu School of Philosophy.

Sindane, J., \& Liebenberg, I. (2000). Reconstruction and the reciprocal other: The philosophy and practice of Ubuntu and democracy in African society. Politeia, 19(3), 31-46. 
Sorkin, D. (1983). Wilhelm Von Humboldt: The theory and practice of self-formation (Bildung), 1791-1810. Journal of the History of Ideas, 44(1), 55-73.

Swanson, D. (2005). Ubuntu: An African contribution to a narrative journey of seeking a humble togetherness, paper presented at the annual conference of the Comparative and International Education Society (West), The University of British Columbia, Vancouver, Canada.

Taylor, C. (1991). Cross-purposes: The liberal-communitarian debate. In N. L. Rosenblum (Ed.), Liberalism and the moral life. Massachusetts: Harvard University Press.

Taylor, C. (1996). Communitarianism, Taylor-made: An interview with Charles Taylor. Australian Quarterly, 68(2), 1-10.

Teffo, L. J. (1994). The concept of Ubuntu as a cohesive moral value. Pretoria: Ubuntu School of Philosophy.

Tshoose, C. I. (2009). The emerging role of the constitutional value of Ubuntu for informal social security in South Africa. African Journal of Legal Studies, 3, 12-19.

Tutu, D. (1999). No future without forgiveness. London: Rider.

Waldron, J. (2002). Is the rule of law an essentially contested concept (in Florida)? Law and Philosophy, 21(2), 137-164.

Wiredu, K. (1996). Cultural universals and particulars: An African perspective. Bloomington, Indianapolis: Indiana University Press.

Wolf, E. R. (1982). Europe and the people without history. Berkeley: University of California Press.

Wulf, C. (2003). Perfecting the Individual: Wilhelm von Humboldt's concept of anthropology, Bildung and mimesis. Educational Philosophy and Theory, 35(2), 241-249. 